\title{
Virus-Induced Gene Silencing, a Post Transcriptional Gene Silencing Method
}

\author{
Turgay Unver ${ }^{1,2}$ and Hikmet Budak ${ }^{1}$ \\ ${ }^{1}$ Biological Sciences \& Bioengineering Program, Faculty of Engineering and Natural Sciences, Sabanci University, \\ Orhanli, Tuzla, Turkey \\ ${ }^{2}$ Kocaeli University, Arslanbey MYO, Izmit, Turkey
}

Correspondence should be addressed to Hikmet Budak, budak@sabanciuniv.edu

Received 1 December 2008; Accepted 30 March 2009

Recommended by Chunji Liu

Virus-induced gene silencing (VIGS) is one of the reverse genetics tools for analysis of gene function that uses viral vectors carrying a target gene fragment to produce dsRNA which trigger RNA-mediated gene silencing. There are a number of viruses which have been modified to silence the gene of interest effectively with a sequence-specific manner. Therefore, different types of methodologies have been advanced and modified for VIGS approach. Virus-derived inoculations are performed on host plants using different methods such as agro-infiltration and in vitro transcriptions. VIGS has many advantages compared to other lossof-gene function approaches. The approach provides the generation of rapid phenotype and no need for plant transformation. The cost of VIGS experiment is relatively low, and large-scale analysis of screening studies can be achieved by the VIGS. However, there are still limitations of VIGS to be overcome. Nowadays, many virus-derived vectors are optimized to silence more than one host plant such as TRV-derived viral vectors which are used for Arabidopsis and Nicothiana benthamiana. By development of viral silencing systems monocot plants can also be targeted as silencing host in addition to dicotyledonous plants. For instance, Barley stripe mosaic virus (BSMV)-mediated VIGS allows silencing of barley and wheat genes. Here we summarize current protocols and recent modified viral systems to lead silencing of genes in different host species.

Copyright ( $\odot 2009$ T. Unver and H. Budak. This is an open access article distributed under the Creative Commons Attribution License, which permits unrestricted use, distribution, and reproduction in any medium, provided the original work is properly cited.

\section{Introduction}

Gene silencing at posttranscriptional level, posttranscriptional gene silencing (PTGS), is an RNA-mediated systemic silencing mechanism which was described as quelling in fungi [1] and RNA interference in animals [2]. To specifically silence or knock down the expression of targeted gene in plants several approaches of PTGS have been developed. Virus-Induced Gene Silencing (VIGS) is one of these tools to suppress expression level of the gene of interest in plants $[3,4]$. The term VIGS was first coined by A. van Kammen to describe the resistance event against viral infection [5]. Plants infected by many viruses induce RNA-mediated defense which targets viral RNAs and any transgene RNA products inserted into it [6]. As a gene silencing method VIGS has several advantageous such as fast, transient suppression of gene expression, and it involves cloning of short sequence fragments of targeted gene to be silenced. As a reverse genetic approach VIGS provides silencing of target gene in sequence specific manner. RNA-induced gene silencing mechanism is also acting on VIGS in which 21-25 nucleotide sequence of small interfering RNAs (siRNAs) guides specific cleavage or suppression of target mRNAs at posttranscriptional level $[2,7]$. siRNAs which are processed from long double-stranded RNAs (dsRNA) by DICER, an RNAse-like enzyme, are then incorporated into RNA-induced silencing complex (RISC). This complex with siRNA targets specific mRNA transcripts having sequence complementarity with the specific siRNA. In other words the antisense strand of the siRNA associates with the RNAi silencing complex (RISC) to target homologous RNA for degradation [8]. dsRNAs may be originated in infected plant during cytoplasmic replication of positive-sense single-stranded (ss)RNA viruses and in the case of replicative form and replicative intermediates may represent the pool of dsRNAs [6]. For transgenes dsRNA may be generated by host RNA dependent 
RNA polymerases (RdRp) [9]. To be a PTGS inducers transgenes also designed and constructed to produce dsRNA $[10]$.

\section{Development of VIGS Methodology}

Some virus species were previously modified and used for silencing the gene of interest (Table 1). Tobacco mosaic virus (TMV) is one of the modified viruses which was used for effective $p d s$ gene silencing in Nicotiana benthamiana plants [11]. TMV is the first modified virus for application of VIGS methods to plants. The viral delivery leads downregulation of transcript of target gene through its homology dependent degradation so potential of VIGS for analysis of gene function was easily recognized [3]. Thomas et al. detected the minimum length of RNA for PTGS. A minimum of 23 nucleotide possessing 100\% homology to the target gene was observed to be required but not enough for efficient PTGS, and longer identical sequence is needed to initiate silencing $[12,13]$. Tobacco rattle virus (TRV) was also modified to be a tool for gene silencing in plants. VIGS has been effectively applied in N. benthamiana [14] and in tomato [15] by using TRV vectors. The significant advantage of TRV-based VIGS in Solanaceous species is the ease of introduction of the VIGS vector into plants. The VIGS vector is placed between Rigth Border (RB) and Left Border (LB) sites of TDNA and inserted into Agrobacterium tumefaciens $[15,16]$. Another property of TRV is the more vigorous spreading all over the entire plant including meristem, and infection symptoms of TRV are mild [15]. Modified TRV vectors such as pYL156 and pYL279 have strong duplicate 35S promoter and a ribozyme at C-terminus for more efficient and faster spreading. These vectors are also able to infect other plant species $[13,14]$. TRV-based vector has been used by Liu et al. for gene silencing in tomato [14]. Dalmay et al. have also used TRV-based VIGS to silence gene in A. thaliana [9]. BurchSmith et al. [17] have developed an efficient TRV-based VIGS method to silence the $A$. thaliana genes with minimal modification of widely used TRV-based VIGS technique. Very recently, Pflieger et al. [18] have shown that a viral vector derived from Turnip yellow mosaic virus [TYMV) has the ability to induce VIGS in Arabidopsis thaliana. VIGS of N. benthamiana using Potato virus X (PVX) was also achieved [19]. PVX-based vectors have more limited host range (only three families of plants are susceptible to PVX) than TMVbased vectors (nine plant families show susceptibility for TMV) but PVX-based vectors are more stabile compared to TMV [20].

Geminivirus-derived vectors can be used for VIGS studies especially to study function of genes involved in meristem function. Tomato golden mosaic virus (TGMV) was used to silence a meristematic gene, proliferating cell nuclear antigen (PCNA) in N. benthamiana [34]. The TGMV-based silencing vector had been used for also silencing of nonmeristematic gene silencing [39]. Satellite-virus-based vectors are also used for efficient gene silencing in plants only with the help of other helper viruses. This two-component system is called Satellite-virus-induced silencing system, SVISS. In a study Tomato yellow leaf curl China virus being helper and a modified satellite DNA ware used to silence gene in $N$. benthamiana [38]. There are other viruses modified for silencing of dicotyledonous plants such as African cassava mosaic virus in cassava [37], Pea early browning virus in pea [29], and Bean pod mottle virus in soybean [28].

Previously barley stripe mosaic virus (BSMV) was developed for efficient silencing of pds gene in barley [26]. This system was then used for silencing of wheat genes [27]. BSMV is a positive sense RNA virus containing a tripartite $(\alpha, \beta, \gamma)$ genome. The modified $\gamma$ of BSMV genome replaced by DNA vector was used for plant gene cloning. $\beta$ genome has been deleted for viral coat protein production defect. Each of the modified DNAs is used to synthesize RNAs by in vitro transcription. Recently, Brome mosaic virus strain has been modified for VIGS of pds, actin, and rubisco activase. These genes were also silenced in important model plants such as rice [33].

\section{Methods Used in VIGS}

3.1. PVX (Potato Virus X)-Derived VIGS for Potato Silencing. PVX is RNA virus and infects broad range of solanaceous plants. A PVX derivative vector, an agroinfection vector, pGR106, has been previously constructed for gene silencing [19]. The vector was also used for the PVX-mediated VIGS in leaves and tubers of potato plants [21].

3.1.1. Construction of PVX-Derived Vectors. PVX.GFP and PVX.PDS $_{\mathrm{AS}}$ can be constructed via PCR-based cloning using specific oligonucleotide primers incorporating AscI and NotI restrictions sites, respectively, at the $5^{\prime}$ - and $3^{\prime}$-termini into pGR106, a PVX derivative vector (Sainsbury Laboratory, Norwich, UK).

3.1.2. Agrobacterium Tumefaciens Transformation. Transformation procedure can be followed as outlined previously [40]. A. tumefaciens strains (such as LB4404 and GV3101) should be prepared, and $500 \mathrm{~mL}$ of SOB medium (2\% Bacto tryptone, $0.5 \%$ Bacto yeast extract, $10 \mathrm{mM} \mathrm{NaCl}, 2.5 \mathrm{mM}$ $\mathrm{KCl}$ ) in a flask should be inoculated with $1.0 \mathrm{~mL}$ of an overnight culture of bacteria for 6 hours at $28^{\circ} \mathrm{C}$ with shaking till OD550 reaches 0.7 . The culture then chilled on ice for 30 minutes. The cells should be harvested at $6000 \mathrm{rpm}$ for 10 minutes at $4^{\circ} \mathrm{C}$. The pellet will be washed four times with $200 \mathrm{~mL} \mathrm{10 \%} \mathrm{glycerol} \mathrm{(90 \%} \mathrm{sterile} \mathrm{water).} \mathrm{The} \mathrm{final} \mathrm{re-}$ suspension can be made with $0.5 \mathrm{~mL}$ in ice cold $10 \%$ glycerol. The prepared competent cells can be used immediately or stored at $-80^{\circ} \mathrm{C}$ in small aliquots. Transformation of electrocompetent $A$. tumefaciens cells is performed by an electroporator. A prechilled electroporation cuvette is filled with $20-30 \mu \mathrm{L}$ electrocompetent cells and up to $5 \mu \mathrm{L}$ ligation products and should be treated with recommended $330 \mu \mathrm{F}$ capacitance, $4000 \Omega$ resistance, and $380 \mathrm{~V}^{1}$ voltage. Cells are then put into $0.5 \mathrm{~mL}$ of SOC medium and incubated for 1 hour with shaking $(100 \mathrm{rpm})$. The transformed cells are selected via antibiotic selection on spread plates with supplemented selection [40]. 
TABLE 1: Viruses used for silencing of genes and their hosts with targeted genes are listed.

\begin{tabular}{|c|c|c|c|c|c|}
\hline Viruse/viruse type & Silencing host species & Group & Genes silenced & $\begin{array}{l}\text { Natural host } \\
\text { species }\end{array}$ & Reference \\
\hline $\begin{array}{l}\text { Tobacco mosaic virus } \\
\text { (TMV)/RNA virus }\end{array}$ & $\begin{array}{l}\text { Nicotiana } \\
\text { benthamiana, } \\
\text { nicotiana tabacum }\end{array}$ & Tobamovirus & $p d s$ & $\begin{array}{l}\text { Tomato, squash, } \\
\text { potato, tobacco }\end{array}$ & {$[11]$} \\
\hline $\begin{array}{l}\text { Potato virus X } \\
(\mathrm{PVX}) / \mathrm{RNA} \text { virus }\end{array}$ & $\begin{array}{l}\text { Nicotiana } \\
\text { benthamiana, } \\
\text { Arabidopsis }\end{array}$ & Potexvirus & $p d s$ & $\begin{array}{l}\text { Potato, oilseed, } \\
\text { rape }\end{array}$ & {$[21,22]$} \\
\hline $\begin{array}{l}\text { Tobacco rattle virus } \\
\text { (TRV)/RNA virus }\end{array}$ & $\begin{array}{l}\text { Nicotiana } \\
\text { benthamiana, tomato, } \\
\text { Arabidopsi,solanum species, } \\
\text { chilli pepper, opium poppy, } \\
\text { Aquilegia vulgaris }\end{array}$ & Tobravirus & $\begin{array}{l}\text { Rarl, EDS1, } \\
\text { NPR1/NIM1 } \\
p d s, r b c S\end{array}$ & $\begin{array}{l}\text { Spinach, beet, } \\
\text { potato, tobacco }\end{array}$ & {$[14,16,23-25]$} \\
\hline $\begin{array}{l}\text { Barly stripe mosaic virus } \\
\text { (BSMV) RNA virus }\end{array}$ & Barley & Hordeivirus & $\begin{array}{l}p d s, \text { Lr21, Rarl } \\
\text { Sgt1, Hsp90 }\end{array}$ & Barley, wheat & {$[26,27]$} \\
\hline $\begin{array}{l}\text { Bean pod mottle virus } \\
\text { (BPMV)/RNA virus }\end{array}$ & Glycine max & Comovirus & $p d s$ & $\begin{array}{l}\text { Phaseolus } \\
\text { vulgaris,glycine } \\
\max \end{array}$ & {$[28]$} \\
\hline $\begin{array}{l}\text { Pea early browning virus } \\
\text { (PEBV)/RNA viruse }\end{array}$ & $\begin{array}{l}\text { Pisum sativu, } \\
\text { Medicago truncatula, } \\
\text { Lathyrus odorata }\end{array}$ & Tobravirus & $\begin{array}{l}\text { pspds, uni, kor, } \\
\text { pds }\end{array}$ & $\begin{array}{l}\text { Pisum sativum, } \\
\text { Phaseolus } \\
\text { vulgaris }\end{array}$ & {$[29,30]$} \\
\hline $\begin{array}{l}\text { Satellite tobaccomosaic } \\
\text { virus (STMV)/Satellite } \\
\text { virus }\end{array}$ & Nicotiana tabacum & $\begin{array}{l}\text { RNA satellite } \\
\text { virus }\end{array}$ & $\begin{array}{l}p d s, r b c S, r b c L \\
\text { and various } \\
\text { genes }\end{array}$ & $\begin{array}{l}\text { Nicotiana } \\
\text { glauca, pepper }\end{array}$ & {$[31]$} \\
\hline $\begin{array}{l}\text { Poplar mosaic virus } \\
\text { (PopMV)/RNA virus }\end{array}$ & Poplar & Carlavirus & $g f p$ & $\begin{array}{l}\text { Nicotiana } \\
\text { benthamiana }\end{array}$ & {$[32]$} \\
\hline $\begin{array}{l}\text { Brome mosaic virus } \\
\text { (BMV)/RNA virus }\end{array}$ & Barley, rice, maize & Bromovirus & $\begin{array}{l}\text { pds, actin } 1, \\
\text { rubisco activase }\end{array}$ & Barley & {$[33]$} \\
\hline $\begin{array}{l}\text { Tobacco golden mosaic } \\
\text { virus (TGMV)/DNA } \\
\text { virus }\end{array}$ & $\begin{array}{l}\text { Nicotiana } \\
\text { benthamiana, }\end{array}$ & Begomovirus & $s u$ & Tomato & {$[34]$} \\
\hline $\begin{array}{l}\text { Tomato bushy shunt } \\
\text { virus (TBSV)/RNA virus }\end{array}$ & $\begin{array}{l}\text { Nicotiana } \\
\text { benthamiana, }\end{array}$ & Tombusvirus & $g f p$ & $\begin{array}{l}\text { Lycopersicon } \\
\text { esculentum }\end{array}$ & {$[35]$} \\
\hline $\begin{array}{l}\text { Cabbage leaf curl virus } \\
(\mathrm{CaLCuV}) / \mathrm{DNA}\end{array}$ & Arabidopsis & Begomovirus & $\mathrm{CH} 42, \mathrm{pds}$ & $\begin{array}{l}\text { Cabbage, } \\
\text { broccoli, } \\
\text { cauliflower }\end{array}$ & {$[36]$} \\
\hline $\begin{array}{l}\text { African cassava mosaic } \\
\text { virus (ACMV)/DNA } \\
\text { virus }\end{array}$ & $\begin{array}{l}\text { Nicotiana } \\
\text { benthamiana, } \\
\text { Manihot esculenta }\end{array}$ & Begomovirus & $p d s, s u, c y p 79 d 2$ & $\begin{array}{l}\text { Manihot } \\
\text { esculenta }\end{array}$ & {$[37]$} \\
\hline $\begin{array}{l}\text { Tomato yellow leaf curl } \\
\text { China Virus } \\
\text { (TYLCV)/DNA virus }\end{array}$ & $\begin{array}{l}\text { Nicotiana benthamiana, } \\
\text { Lycopersicon esculentum, } \\
\text { N. glutinosa, } \\
\text { N. tabacum }\end{array}$ & $\begin{array}{l}\text { DNAbeta } \\
\text { satellite DNA }\end{array}$ & $\begin{array}{l}p c n a, p d s, s u \\
g f p\end{array}$ & Tomato & {$[38]$} \\
\hline
\end{tabular}


3.1.3. Agrobacterium Infection of Plants. Agrobacterium tumefaciens strain possessing helper plasmid pSoup is generally transformed with PVX.GFP or PVX.GOI using procedure described above. Agroinfiltration of N. benthamiana and Solanum species should be performed as follows. PVX.GOI construct containing A. tumefaciens culture will be grown overnight at $28^{\circ} \mathrm{C}$, harvested at $3000 \mathrm{rpm}$ for 20 minutes, and resuspended in the same volume of $10 \mathrm{mM}$ $\mathrm{MgCl}_{2}$, with $100 \mu \mathrm{M}$ acetosyringone and $1 \mathrm{mM}$ Mes, pH 5.6. The culture should be infiltrated into leaves by a syringe at lower face [40].

3.2. TRV-Derived VIGS for Arabidopsis Silencing. The most widely used viral delivery vectors are Tobacco rattle viruses (TRV, 16] because introduction of virus into plant including is easy in meristematic tissue [16]. TRV-mediated gene silencing was applied to many plants from diverse genera such as Nicotiana benthamiana [14, 16], tomato [15], pepper (Capsicum annuum; 32), potato (Solanum tuberosum; 33), and petunia (Petunia hybrida; 34) from Solanaceae family, opium poppy (Papaver somniferum) from Papaveraceae [23], and Arabidopsis thaliana being a model organism [17]. The TRV silencing in plants is usually mediated by Agrobacterium tumefaciens. TRV vectors PTRV1 and pTRV2 are placed between LB and RB sites separately. One of these vectors pTRV1, is constructed with GOI for targeted gene silencing (Figure 1).

3.2.1. Construction of TRV Vectors and AgrobacteriumMediated Infiltration. The TRV vectors pTRY1 (pYL192) and pTRY2 (pYL156) have been described earlier [14], and the procedure can be followed described by Birch-Smith et al. [17]. XbaI-EcoRI-cut pTRV2 vector is ligated with XbaI-EcoRI-engineered PCR fragment of GOI and then transformed into A. tumefaciens GV3101 strain which is made electrocompotent (described in Section 3.1.2). The Agrobacterium culture transformed with both pTRV1 and pTRV2-GOI (grown in $50 \mathrm{mg} / \mathrm{L}$ gentamycin and $50 \mathrm{mg} / \mathrm{L}$ kanamycin overnight culture) and infiltrated into Arabidopsis leaves by pressing a syringe (described in Section 3.1.3, Figure 1).

3.3. "One-Step" TYMV-Derived Arabidopsis Silencing. Turnip yellow mosaic virus is a positive strand of RNA virus from the genus Tymovirus and infects many Brassicaseae including Arabidopsis [41]. Recently, Pflieger et al. [18] have developed a TYMV-derived vector to induce VIGS in Arabidopsis. The TYMV-derived vector for efficient silencing includes inverted repeats of target gene fragments. The system has ability to silence the gene even expressed in meristem and contains only a single vector. The other advantage of the TYMV mediated VIGS system that allows direct delivery of plasmid DNA to plant cells using rubinoculation is the precluding of in vitro transcription, biolistic, and agroinfiltration steps [18].

3.3.1. Cloning of Plasmid DNAs. The plasmid pTY has been generated by Pflieger et al. [18] using full-length TYMV
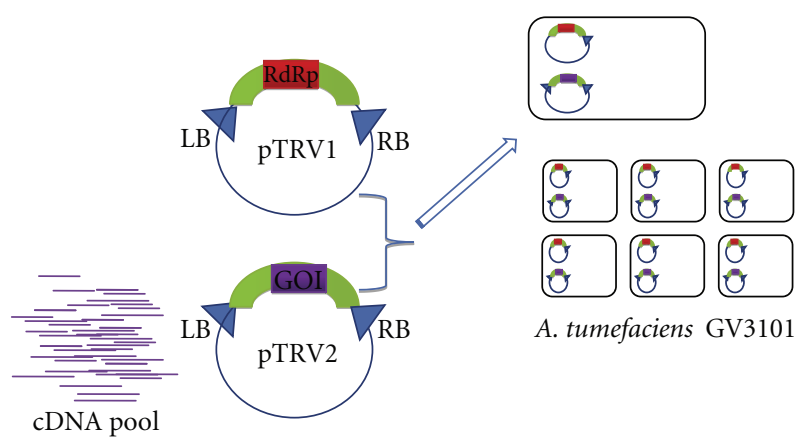

A. tumefaciens GV3101

$$
\text { cD } \overline{N A} \text { of GOI }
$$

(a)
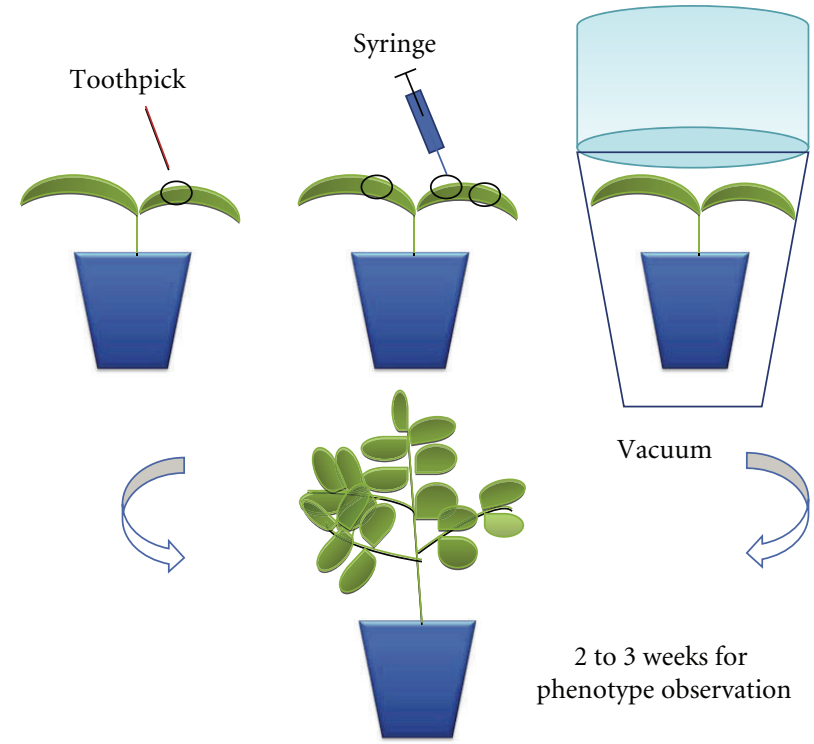

Vacuum

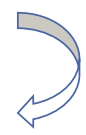

2 to 3 weeks for phenotype observation

(b)

FIGURE 1: TRV-mediated VIGS in N. benthamiana. TRV-based virus induced gene silencing assay covers many steps; the gene with known sequence is first selected and then genetically engineered for cloning into pTRV2. pTRV1 consists of a TRV1-based cassette (RNA-dependent RNA polymerase gene, movement protein, etc.), $\mathrm{LB}$ and $\mathrm{RB}$ site for plant transformation. The plasmids are transformed into A. tumefaciens, and then agro-inoculation is applied. Agrobacterium can be inoculated on plant into seedling by a toothpick, a syringe and a vacuum infiltration as shown in the picture.

cDNA clone under the control of the duplicated CaMV $35 \mathrm{~S}$ promoter and terminator. This vector can be used for efficient gene silencing by cloning the gene(s) of interest into the vector. For example, pTY-PDS52-IR can be obtained by cloning the self-hybridized palindromic oligonucleotides PDS52 into the SnaBI site of pTY-S.

3.3.2. Preparation and Transfection of Protoplasts. Protoplasts of $A$. thaliana can be prepared from cell suspension culture using the procedure described by [42]. A total of 106 protoplasts are transfected DNA plasmids (prepared as 
in Section 3.1), using the quantities indicated. Transfected protoplasts are incubated at $24^{\circ} \mathrm{C}$ in the dark for 48 hours (18).

3.4. Barley Stripe Mosaic Virus (BSMV)-Mediated Silencing. The $\mathrm{p} \gamma \cdot \mathrm{bpds} 4 \mathrm{As}$ can be used to make construction as p $\gamma$.(gene of interest, GOI)As by replacing pds4 insert with short GOI fragment applying restriction digestion. The same procedures can be followed for $\mathrm{p} \gamma$. (gene of interest, GOI)S silencing using p $\gamma$.bpds $4 \mathrm{~S}$ as template [26] (Figure 2).

\subsubsection{Barley and Wheat Pds Gene Silencing and Measurement of Silencing Levels}

Linearization of Plasmids. For linearization, $\mathrm{p} \alpha, \mathrm{p} \beta \Delta \beta \mathrm{a}, \mathrm{p} \gamma$, $\mathrm{p} \gamma \cdot \mathrm{bpds} 4 \mathrm{~S}$, and $\mathrm{p} \gamma$.bpds 4 As plasmids should be digested with following restriction enzymes. $\mathrm{p} \alpha$ plasmid DNA is digested with $M l u I$ enzyme. To perform digestion, $10 \mu \mathrm{g}$ purified $\mathrm{p} \alpha$ plasmid DNA, 1X RE buffer, $10 \mathrm{U}$ MluI enzyme, and PCR grade water are combined in a sterile eppendorf tube to a final volume of $50 \mu \mathrm{L}$. Mixture is incubated at $37^{\circ} \mathrm{C}$ for 2 hours. $B c u I$ enzyme can be used for $\mathrm{p} \beta \Delta \beta$ a plasmid DNA digestion. For digestion, $10 \mu \mathrm{g}$ purified $\mathrm{p} \beta \Delta \beta$ a plasmid DNA, $1 \mathrm{X}, 10 \mathrm{U} B c u \mathrm{I}$ are combined in a sterile tube to reach a final volume of $50 \mu \mathrm{L}$ PCR water is used. Mixture is incubated at $37^{\circ} \mathrm{C}$ for approximately 2 hours. py plasmid can be digested with BssHII enzyme. To generate linearization of p $\gamma$ vectors $10 \mu \mathrm{g}$ p $\gamma$ plasmid DNA, $1 \mathrm{X}$ enzyme buffer, $10 \mathrm{U}$ BssHII enzyme, and PCR grade water are combined in a tube to handle a final volume of $50 \mu \mathrm{L}$. Mixture is generally incubated at $50^{\circ} \mathrm{C}$ for $2-3$ hours. After the incubation samples should be observed on 1\% agarose gel. Linearized plasmids should then be excised and purified [26, 27, 43].

In Vitro Transcription. In vitro transcription is performed for the silencing of selected target gene. It requires at least three separate in vitro transcription reactions which are the transcription of $\alpha, \beta \Delta \beta \mathrm{a}$, and $\gamma$ linearized genomes. According to manufacturer's procedure mMessage mMachine T7 in vitro transcription kit (cat no: 1344, Ambion, Austin, TX) transcriptions are performed. Components are mixture in a sterile tube: separately for each linarized plasmids (MluI digested $\mathrm{p} \alpha-B c u$ I digested $\mathrm{p} \beta \Delta \beta \mathrm{a}, B s \mathrm{HII}$ digested $\mathrm{p} \gamma$ - or $B s s \mathrm{HII}$ digested $\mathrm{p} \gamma \cdot \mathrm{bpds} 4 \mathrm{~S}$ and $B s \mathrm{HII}$ digested $\mathrm{p} \gamma \cdot \mathrm{bpds} 4 \mathrm{As}$ ) $80 \mathrm{ng}$ template is used per one silencing reaction (linearized plasmid DNA), 1X Buffer (Ambion), 1X nucleotide mix with NTP Cap (Ambion), $0.3 \mu \mathrm{L}$ of T7 RNA polymerase mix (Ambion), and sterile distilled water are combined up to $3 \mu \mathrm{L}$. Mixture is incubated at $37^{\circ} \mathrm{C}$ for 2 hours and stored at $-80^{\circ} \mathrm{C}$ until use $[26,27,43]$.

BSMV Transcript Inoculations on Plants. Barley and wheat plants can be used for BSMV-mediated PTGS. The second leaves (approximately 7-10 days upon germination) should be inoculated with BSMV for silencing. All BSMV transcripts which are $\alpha, \beta \Delta \beta \mathrm{a}$, and $\gamma$ will be mixed in a $1: 1: 1$ ratio (1.0-1.5 $\mu$ g of each transcript concentration is observed on spectrophotometer, Figure 2, Table 2). Transcription mix is combined with $50 \mu \mathrm{L}$ FES. $50 \mathrm{~mL}$ FES requires GP solution (10X GP: (18.77 g glycine, 26.13 g K2HPO4, $\mathrm{ddH}_{2} \mathrm{O}$ upto $500 \mathrm{~mL}$, sterilized by 20 minute autoclaving) which is then combined with $2.5 \mathrm{~g}$ sodium pyrophosphate, $2.5 \mathrm{~g}$ bentonite, $2.5 \mathrm{~g}$ celite with $\mathrm{ddH}_{2} \mathrm{O}$ up to $250 \mathrm{~mL}$ and re-autoclaved [44], and directly applied to the second leaf (when it is 5$7 \mathrm{~cm}$ long) from the bottom of leaf to the tip. After 7-10 days post inoculation (dpi), appearance of mosaic symptoms on leaves should be observed showing systemic spread of the virus. Leaves from inoculated plants are collected after approximately 14-15 day postinoculation (dpi) in order to check $p d s$ gene silencing level by qRT-PCR $[26,43]$.

\section{Improvements of Virus-Induced Gene Silencing}

Gene specific silencing via VIGS system is now used for diverse monocot and dicot plant species. Therefore, a number of viral-derived vectors have been developed (Table 1), and many procedures have been optimized by the researchers. TRV system was efficiently optimized for efficient silencing of Solanaceous plants [14, 15], and the system was also applied for tomato to study role of fruit ripening genes [45]. TRV-mediated VIGS has been modified for robust and effective gene silencing in a model organism, Arabidopsis by [17]. The emerging model plant columbine Aquilegia vulgaris has been efficiently silenced via TRVmediated VIGS [24]. Many economically important plants were studied to optimize TRV-derived VIGS silencing such as opium poppy [23]. Efficiency of the TRV-derived viral vector used VIGS system on tomato fruit via agro-injection has been improved up to $90 \%$ silencing compared to agroinfiltration of cotyledons and first leaves of plants $(66 \%)$ [46]. Lacomme et al. [47] have described a method to enhance the robustness of the VIGS phenotype by increasing the level of dsRNA by incorporation of 40-60 base direct inverted-repeats into a plant viral vector. Cheapness and easiness of Arabidopsis silencing have been improved via "one-step"TYMV-derived VIGS [18]. Monocot plants are also subjected to be silenced via VIGS. For this propose, Holzberg et al. [26] developed a BSMV-mediated VIGS system for barley, and Scofield et al. [27] have applied the system to wheat. BMV has also been used to silence genes in monocot plants. Ding et al. [33] efficiently silenced the genes in barley, rice and maize.

\section{Comparison of VIGS with Other Gene Silencing Methods}

VIGS has many advantages and disadvantages compared to other techniques used for functional analysis of plant genes. Generally, the method is chosen for its reliability, low cost, easiness, and rapidness. Several tools have been used for identification of loss-of-function of gene(s) such as, TILLING, chemical and physical mutagenesis, T-DNA, and transposon insertion techniques. However, VIGS presents an intended potential for the researchers working with 


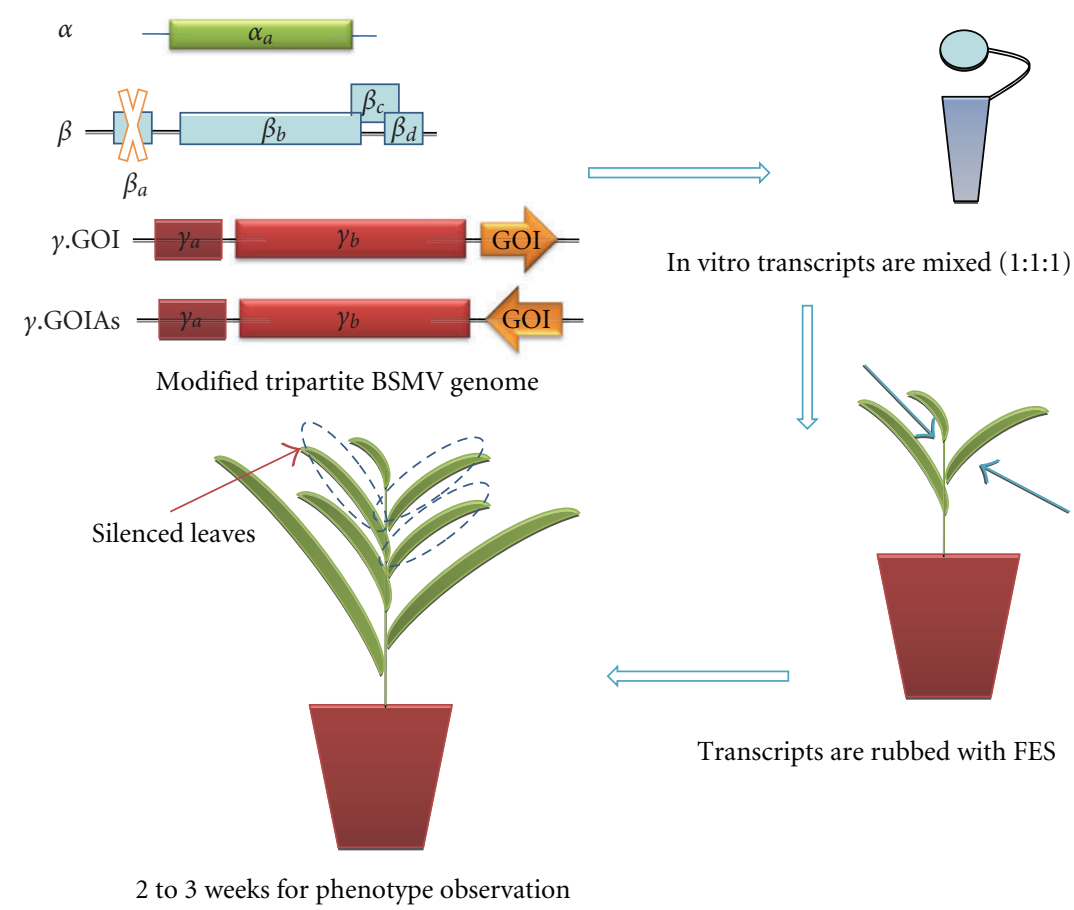

FIGURE 2: BSMV-mediated VIGS in barley. Barley stripe mosaic virus has a tripartite genome, and it has been modified to specific VIGS in barley plants $[26,27,43]$.

TABLE 2: Construction of transcripts for the BSMV inoculation [26, 27, 43].

\begin{tabular}{|c|c|c|c|c|c|c|}
\hline Inoculation for silencing & $\begin{array}{c}\mathrm{p} \alpha \\
\text { transcript }\end{array}$ & $\underset{\text { transcript }}{\mathrm{p} \beta \Delta \beta \mathrm{a}}$ & $\begin{array}{c}\mathrm{p} \gamma \\
\text { transcript }\end{array}$ & $\begin{array}{l}\mathrm{p} \gamma . \mathrm{GOIS} \\
\text { transcript }\end{array}$ & $\begin{array}{l}\mathrm{p} \gamma \cdot \mathrm{GOIAs} \\
\text { transcript }\end{array}$ & $\begin{array}{c}\text { FES } \\
\text { solution }\end{array}$ \\
\hline BSMV:00 (viral control) & $1.0-1.5 \mu \mathrm{g}$ & $1.0-1.5 \mu \mathrm{g}$ & $1.0-1.5 \mu \mathrm{g}$ & - & - & $50-55 \mu \mathrm{L}$ \\
\hline BSMV:GOIS (sense version) & $1.0-1.5 \mu \mathrm{g}$ & $1.0-1.5 \mu \mathrm{g}$ & - & $1.0-1.5 \mu \mathrm{g}$ & - & $50-55 \mu \mathrm{L}$ \\
\hline BSMV:GOIAs (anti-sense version) & $1.0-1.5 \mu \mathrm{g}$ & $1.0-1.5 \mu \mathrm{g}$ & - & - & $1.0-1.5 \mu \mathrm{g}$ & $50-55 \mu \mathrm{L}$ \\
\hline FES (non silencing control) & - & - & - & - & - & $50-55 \mu \mathrm{L}$ \\
\hline
\end{tabular}

functional genomics due to the fact that it avoids many of limitations of the above approaches. Its main advantage is the generation of rapid phenotype and that there is no need for plant transformation. The cost of VIGS experiment is relatively low; Agrobacterium or in vitro transcription mediated VIGS assays do not cost effectively. VIGS method also provides a large-scale screening of genes for functional analysis. Moreover, there is no need to screen large populations to detect the function of a specific gene; only a single plant is enough to follow phenotype with targeted silencing. Therefore, repeating the experiment is easy and time effective. Host range wideness of viral vectors is the other versatility of the approach. For instance TRV can infect spinach, beet, potato, and tobacco naturally. Hence TRVbased VIGS is applied to Nicotiana benthamiana, tomato, Arabidopsis, chilli pepper, opium poppy, and Aquilegia vulgaris(Table 1). Since it does not require plant transformation, VIGS is particularly useful on plants which are difficult or impossible to transform. Therefore, VIGS system can be applied to the genes associated with embryonic development or essential housekeeping functions in plants [33, 38]. Functional redundancy problem is overcome by VIGS application using most conserved region of the gene family $[26,27]$. Despite the valuable advantages of VIGS approach, there are also limitations. One of the most important limitation is that complete loss-of-function by VIGS might not be achieved. Generally 75-90\% downregulation in the expression level of the targeted gene is accomplished [18, $43,46]$. Unfortunately the low level of gene expression can be enough to produce functional protein and phenotype in silenced plant. Some of viral infections can cause symptoms on plant that might mask the phenotype caused by the phenotype. This problem might be minimized as TRV-VIGS system because of mild symptoms $[14,16]$. VIGS aims to silence the specific gene, which can only be achieved by sequence specific manner so the system relays on sequence information. The approach also depends on pathogen-host interaction, so the disadvantage is that pathogen infection may manipulate host function and alter development and morphology. There should be positive control in all VIGS assays to mark the effect of viral inoculation on silenced plant. Lastly, VIGS might suppress nontargeted gene in silenced plant cell or tissue [17]. This response should be addressed before the next genomic era. 


\section{Concluding Remarks}

VIGS as a reverse genetics tool for functional genomics studies presenting many advantages promises rapid generation of functional genomics even proteomics. By the progressing and completing whole genome sequencing of many important crops, VIGS approach will be widely and mostly used. Despite its great potential to extensively use, many limitations remains to be overcome. Firstly host range of viral vectors will become wider; the VIGS assays and viral vectors for model organisms such as Arabidopsis and rice should be well optimized. As mentioned sequence information is crucial for VIGS approach so the whole genome sequence databases and EST databases will be add great contribution of VIGS usage. With the whole genome sequence availability, Brachypodium distachyon (L.) Beauv., a model temperate grass species, should also be used in application of VIGS system for generation of genomics information to improve temperate crops. Large-scale screening via VIGS-based method to detect important and fascinating phenotypes should be performed.

\section{References}

[1] N. Romano and G. Macino, "Quelling: transient inactivation of gene expression in Neurospora crassa by transformation with homologous sequences," Molecular Microbiology, vol. 6, no. 22, pp. 3343-3353, 1992.

[2] A. Fire, S. Xu, M. K. Montgomery, S. A. Kostas, S. E. Driver, and C. C. Mello, "Potent and specific genetic interference by double-stranded RNA in caenorhabditis elegans," Nature, vol. 391, no. 6669, pp. 806-811, 1998.

[3] D. C. Baulcombe, "Fast forward genetics based on virusinduced gene silencing," Current Opinion in Plant Biology, vol. 2, no. 2, pp. 109-113, 1999.

[4] S. P. Dinesh-Kumar, R. Anandalakshmi, R. Marathe, M. Schiff, and Y. Liu, "Virus-induced gene silencing," Methods in Molecular Biology, vol. 236, pp. 287-294, 2003.

[5] A. van Kammen, "Virus-induced gene silencing in infected and transgenic plants," Trends in Plant Science, vol. 2, no. 11, pp. 409-411, 1997.

[6] O. Voinnet, "RNA silencing as a plant immune system against viruses," Trends in Genetics, vol. 17, no. 8, pp. 449-459, 2001.

[7] U. Klahre, P. Crété, S. A. Leuenberger, V. A. Iglesias, and F. Meins Jr., "High molecular weight RNAs and small interfering RNAs induce systemic posttranscriptional gene silencing in plants," Proceedings of the National Academy of Sciences of the United States of America, vol. 99, no. 18, pp. 11981-11986, 2002.

[8] D. P. Bartel, "MicroRNAs: genomics, biogenesis, mechanism, and function," Cell, vol. 116, no. 2, pp. 281-297, 2004.

[9] T. Dalmay, A. Hamilton, S. Rudd, S. Angell, and D. C. Baulcombe, "An RNA-dependent RNA polymerase gene in Arabidopsis is required for posttranscriptional gene silencing mediated by a transgene but not by a virus," Cell, vol. 101, no. 5, pp. 543-553, 2000.

[10] C. F. Chuang and E. M. Meyerowitz, "Specific and heritable genetic interference by double-stranded RNA in Arabidopsis thaliana," Proceedings of the National Academy of Sciences of the United States of America, vol. 97, no. 9, pp. 4985-4990, 2000.
[11] M. H. Kumagai, J. Donson, G. Della-Cioppa, D. Harvey, K. Hanley, and L. K. Grill, "Cytoplasmic inhibition of carotenoid biosynthesis with virus-derived RNA," Proceedings of the National Academy of Sciences of the United States of America, vol. 92, no. 5, pp. 1679-1683, 1995.

[12] C. L. Thomas, L. Jones, D. C. Baulcombe, and A. J. Maule, "Size constraints for targeting post-transcriptional gene silencing and for RNA-directed methylation in Nicotiana benthamiana using a potato virus X vector," The Plant Journal, vol. 25, no. 4, pp. 417-425, 2001.

[13] S. K. Ekengren, Y. Liu, M. Schiff, S. P. Dinesh-Kumar, and G. B. Martin, "Two MARK cascades, NPR1, and TGA transcription factors play a role in Pto-mediated disease resistance in tomato," The Plant Journal, vol. 36, no. 6, pp. 905-917, 2003.

[14] Y. Liu, M. Schiff, R. Marathe, and S. P. Dinesh-Kumar, "Tobacco Rar1, EDS1 and NPR1/NIM1 like genes are required for $\mathrm{N}$-mediated resistance to tobacco mosaic virus," The Plant Journal, vol. 30, no. 4, pp. 415-429, 2002.

[15] Y. Liu, M. Schiff, and S. P. Dinesh-Kumar, "Virus-induced gene silencing in tomato," The Plant Journal, vol. 31, no. 6, pp. 777786, 2002.

[16] F. Ratcliff, A. M. Martín-Hernández, and D. C. Baulcombe, "Tobacco rattle virus as a vector for analysis of gene function by silencing," The Plant Journal, vol. 25, no. 2, pp. 237-245, 2001.

[17] T. M. Burch-Smith, M. Schiff, Y. Liu, and S. P. Dinesh-Kumar, "Efficient virus-induced gene silencing in Arabidopsis," Plant Physiology, vol. 142, no. 1, pp. 21-27, 2006.

[18] S. Pflieger, S. Blanchet, L. Camborde, et al., "Efficient virusinduced gene silencing in Arabidopsis using a 'one-step' TYMV-derived vector,” The Plant Journal, vol. 56, no. 4, pp. 678-690, 2008.

[19] R. Lu, I. Malcuit, P. Moffett, et al., "High throughput virusinduced gene silencing implicates heat shock protein 90 in plant disease resistance," The EMBO Journal, vol. 22, no. 21, pp. 5690-5699, 2003.

[20] T. M. Burch-Smith, J. C. Anderson, G. B. Martin, and S. P. Dinesh-Kumar, "Applications and advantages of virusinduced gene silencing for gene function studies in plants," The Plant Journal, vol. 39, no. 5, pp. 734-746, 2004.

[21] O. Faivre-Rampant, E. M. Gilroy, K. Hrubikova, et al., "Potato virus $\mathrm{X}$-induced gene silencing in leaves and tubers of potato," Plant Physiology, vol. 134, no. 4, pp. 1308-1316, 2004.

[22] M. T. Ruiz, O. Voinnet, and D. C. Baulcombe, "Initiation and maintenance of virus-induced gene silencing," The Plant Cell, vol. 10, no. 6, pp. 937-946, 1998.

[23] L. C. Hileman, S. Drea, G. de Martino, A. Litt, and V. F. Irish, "Virus-induced gene silencing is an effective tool for assaying gene function in the basal eudicot species Papaver somniferum (opium poppy)," The Plant Journal, vol. 44, no. 2, pp. 334-341, 2005.

[24] B. Gould and E. M. Kramer, "Virus-induced gene silencing as a tool for functional analyses in the emerging model plant Aquilegia (columbine, Ranunculaceae)," The Plant Methods, vol. 3, no. 1, article 6, pp. 1-12, 2007.

[25] E. Chung, E. Seong, Y. C. Kim, et al., "A method of high frequency virus-induced gene silencing in chili pepper (Capsicum annuum L. cv. Bukang)," Molecules and Cells, vol. 17, no. 2, pp. 377-380, 2004.

[26] S. Holzberg, P. Brosio, C. Gross, and G. P. Pogue, "Barley stripe mosaic virus-induced gene silencing in a monocot plant," The Plant Journal, vol. 30, no. 3, pp. 315-327, 2002.

[27] S. R. Scofield, L. Huang, A. S. Brandt, and B. S. Gill, "Development of a virus-induced gene-silencing system for 
hexaploid wheat and its use in functional analysis of the Lr21mediated leaf rust resistance pathway," Plant Physiology, vol. 138, no. 4, pp. 2165-2173, 2005.

[28] C. Zhang and S. A. Ghabrial, "Development of Bean pod mottle virus-based vectors for stable protein expression and sequence-specific virus-induced gene silencing in soybean," Virology, vol. 344, no. 2, pp. 401-411, 2006.

[29] G. D. Constantin, B. N. Krath, S. A. MacFarlane, M. Nicolaisen, E. Johansen, and O. S. Lund, "Virus-induced gene silencing as a tool for functional genomics in a legume species," The Plant Journal, vol. 40, no. 4, pp. 622-631, 2004.

[30] M. Grønlund, G. Constantin, E. Piednoir, J. Kovacev, I. E. Johansen, and O. S. Lund, "Virus-induced gene silencing in Medicago truncatula and Lathyrus odorata," Virus Research, vol. 135, no. 2, pp. 345-349, 2008.

[31] V. Gosselé, I. Faché, F. Meulewaeter, M. Cornelissen, and M. Metzlaff, "SVISS - a novel transient gene silencing system for gene function discovery and validation in tobacco plants," The Plant Journal, vol. 32, no. 5, pp. 859-866, 2002.

[32] M. Naylor, J. Reeves, J. I. Cooper, M.-L. Edwards, and H. Wang, "Construction and properties of a gene-silencing vector based on Poplar mosaic virus (genus Carlavirus)," Journal of Virological Methods, vol. 124, no. 1-2, pp. 27-36, 2005.

[33] X. S. Ding, W. L. Schneider, S. R. Chaluvadi, M. A. Rouf Mian, and R. S. Nelson, "Characterization of a Brome mosaic virus strain and its use as a vector for gene silencing in monocotyledonous hosts," Molecular Plant-Microbe Interactions, vol. 19, no. 11, pp. 1229-1239, 2006.

[34] C. Peele, C. V. Jordan, N. Muangsan, et al., "Silencing of a meristematic gene using geminivirus-derived vectors," The Plant Journal, vol. 27, no. 4, pp. 357-366, 2001.

[35] H. Hou and W. Qiu, "A novel co-delivery system consisting of a Tomato bushy stunt virus and a defective interfering RNA for studying gene silencing," Journal of Virological Methods, vol. 111, no. 1, pp. 37-42, 2003.

[36] M. A. Turnage, N. Muangsan, C. G. Peele, and D. Robertson, "Geminivirus-based vectors for gene silencing in Arabidopsis," The Plant Journal, vol. 30, no. 1, pp. 107-114, 2002.

[37] I. B. F. Fofana, A. Sangaré, R. Collier, C. Taylor, and C. M. Fauquet, "A geminivirus-induced gene silencing system for gene function validation in cassava," Plant Molecular Biology, vol. 56, no. 4, pp. 613-624, 2004.

[38] X. Tao and X. Zhou, "A modified viral satellite DNA that suppresses gene expression in plants," The Plant Journal, vol. 38, no. 5, pp. 850-860, 2004.

[39] S. Kjemtrup, K. S. Sampson, C. G. Peele, et al., "Gene silencing from plant DNA carried by a geminivirus," The Plant Journal, vol. 14, no. 1, pp. 91-100, 1998.

[40] R. Lu, A. M. Malcuit, J. R. Martín-Hernández, I. Malcuit, and D. C. Baulcombe, "Virus-induced gene silencing in plants," Methods, vol. 30, no. 4, pp. 296-303, 2003.

[41] D. Martínez-Herrera, J. Romero, J. M. Martínez-Zapater, and F. Ponz, "Suitability of Arabidopsis thaliana as a system for the study of plant-virus interactions," Fitopatologia, vol. 29, pp. 132-136, 1994.

[42] A. Jakubiec, G. Drugeon, L. Camborde, and I. Jupin, "Proteolytic processing of turnip yellow mosaic virus replication proteins and functional impact on infectivity," Journal of Virology, vol. 81, no. 20, pp. 11402-11412, 2007.

[43] T. Unver, Detection and characterization of plant genes involved in various biotic and abiotic stress conditions using DDRTPCR and isolation of interacting proteins, Ph.D. thesis, Middle East Technical University, Institute of Natural and Applied Sciences, Ankara, Turkey, 2008.
[44] G. P. Pogue, J. A. Lindbo, W. O. Dawson, and T. H. Turpen, Tobamovirus Transient Expression Vectors: Tools for Plant Biology and High-Level Expression of Foreign Proteins in Plants, Kluwer Academic Publishers, Dordrecht, The Netherlands, 1998.

[45] D. Q. Fu, B. Z. Zhu, H. L. Zhu, W. B. Jiang, and Y. B. Luo, "Virus-induced gene silencing in tomato fruit," The Plant Journal, vol. 43, no. 2, pp. 299-308, 2005.

[46] D. Orzaez, S. Mirabel, W. H. Wieland, and A. Granell, "Agroinjection of tomato fruits. A tool for rapid functional analysis of transgenes directly in fruit," Plant Physiology, vol. 140, no. 1, pp. 3-11, 2006.

[47] C. Lacomme, K. Hrubikova, and I. Hein, "Enhancement of virus-induced gene silencing through viral-based production of inverted-repeats," The Plant Journal, vol. 34, no. 4, pp. 543553, 2003. 

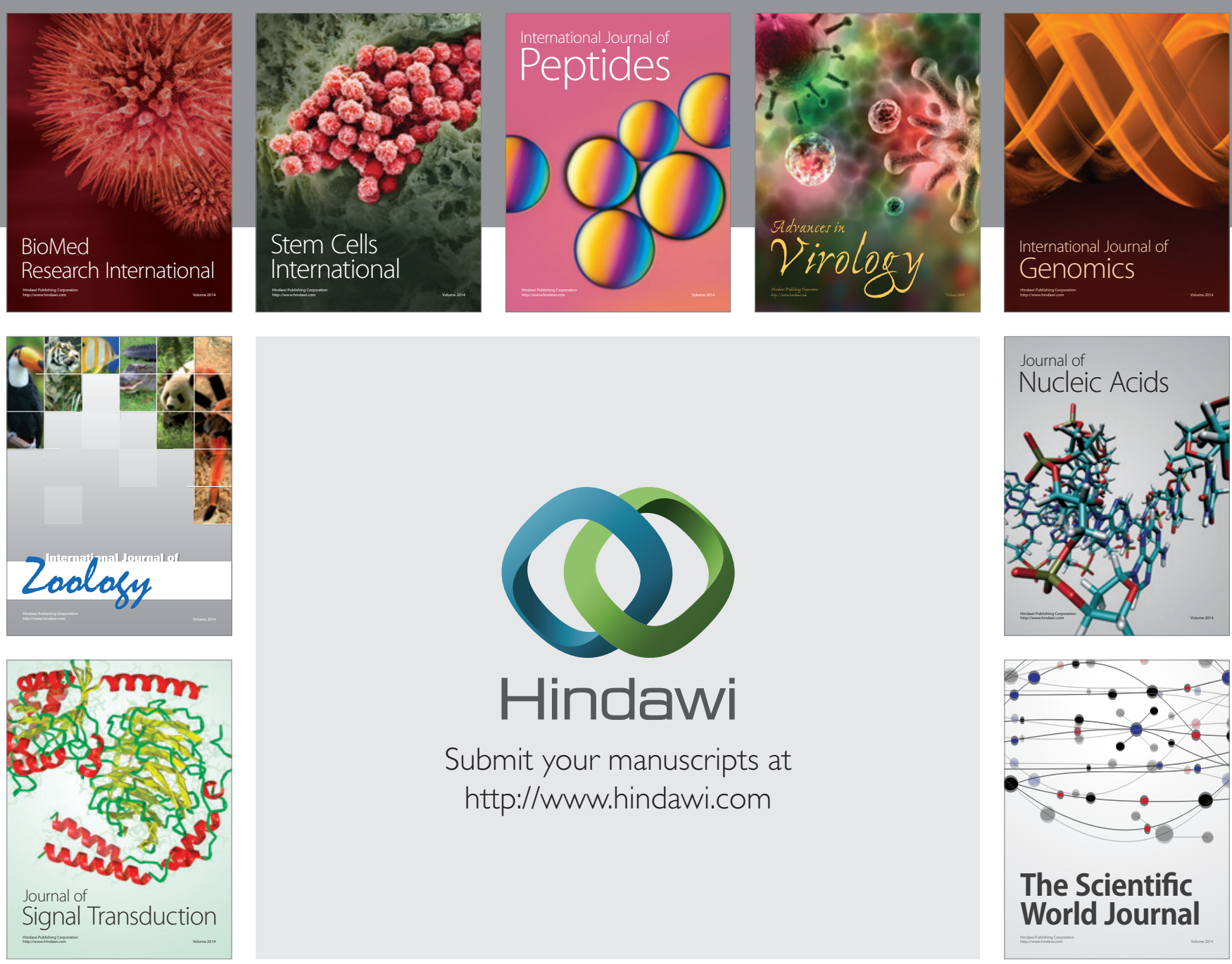

Submit your manuscripts at

http://www.hindawi.com
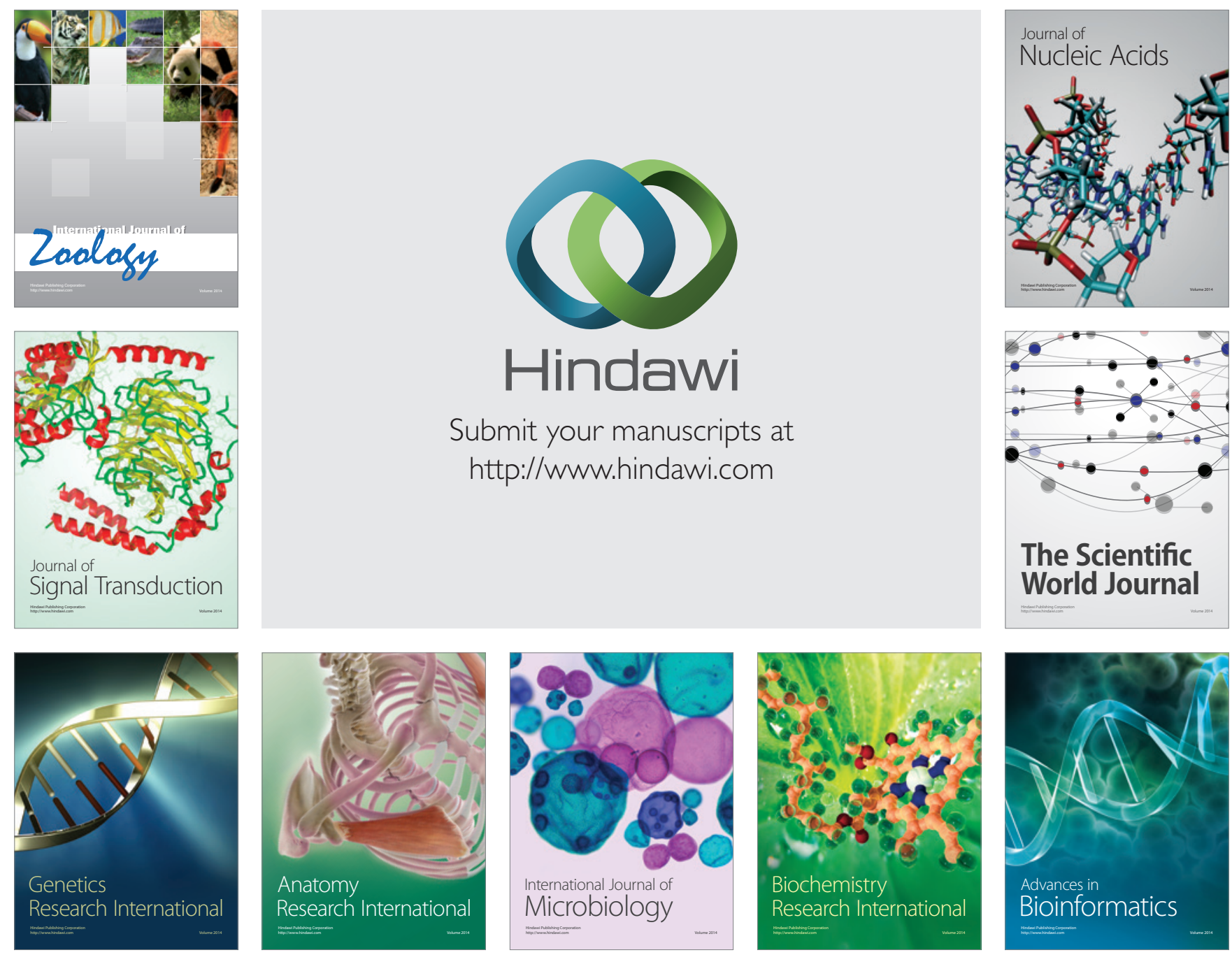

The Scientific World Journal
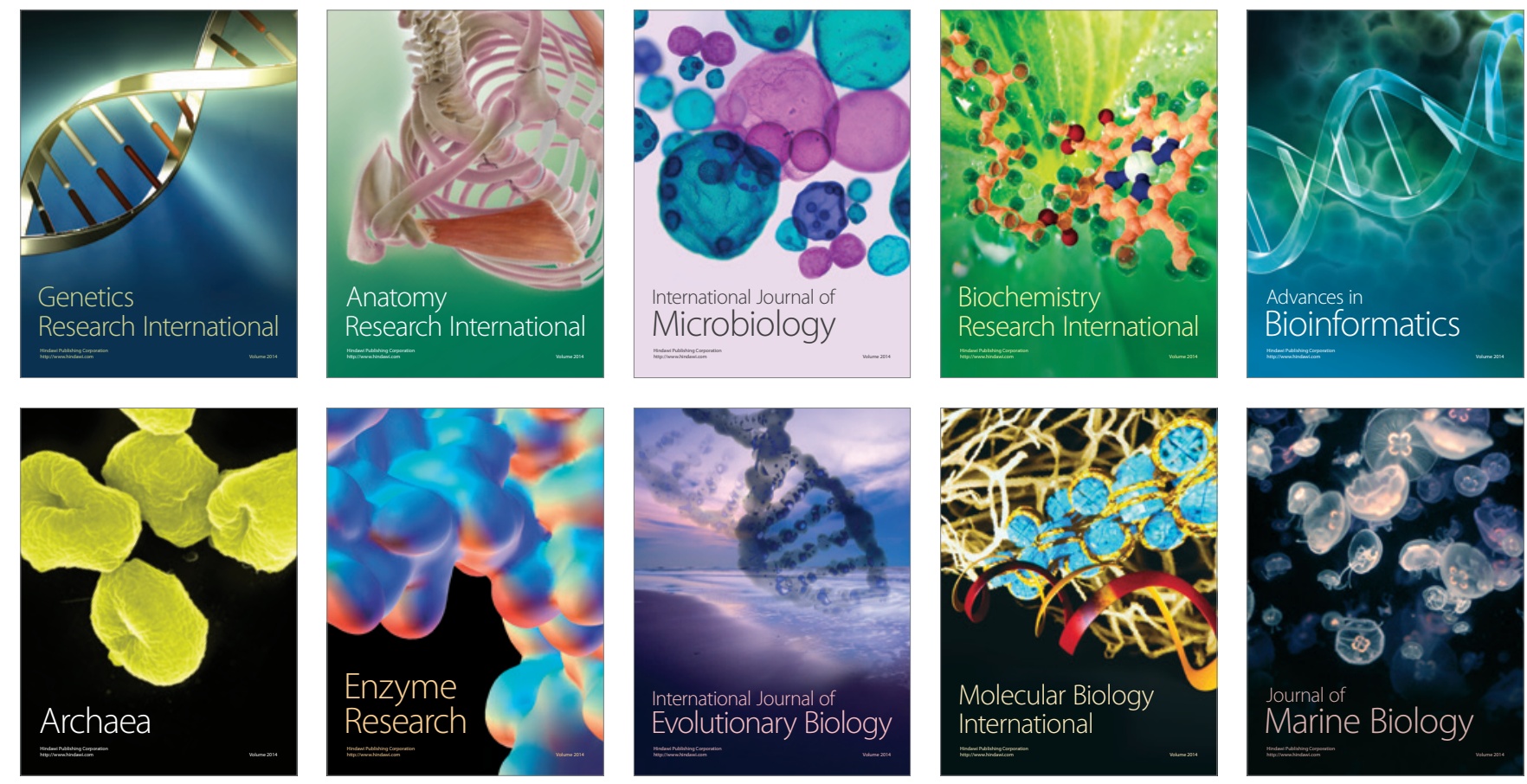